19 (4): 395 - 407 (2020)

(ㅇ / ISSN 07177917 / www.blacpma.ms-editions.cl

\title{
Articulo Original / Original Article \\ Characterization of Persea americana Mill. peels and leaves extracts and analysis of its potential in vitro anti-inflammatory properties
}

\author{
[Caracterización de extractos de piel y hojas de Persea americana Mill. y analisis in vitro de sus potenciales \\ propiedades anti-inflamatorias]
}

\author{
Angelica Ovalle-Marin, Claudia Parra-Ruiz, Francisca Rivas, Juan Francisco Orellana, \\ Diego F. Garcia-Diaz \& Paula Jimenez
}

Department of Nutrition, School of Medicine, University of Chile. Santiago, Chile

Contactos | Contacts: Paula JIMENEZ - E-mail address: paulajimenez@med.uchile.cl

\begin{abstract}
There is a worldwide trend of increasing prevalence of non-communicable diseases characterized by a chronic inflammatory state. Therefore, it is important to study the relationship between food and health. Avocado (Persea americana) stands out in food industry for its nutritional value. Industrials process of avocado generates a large number of by-products, which contain phytochemical compounds with antioxidant properties, such as polyphenols. The objective of the present research was to characterize four aqueous and hydroalcoholic extracts from avocado leaves and peels and analyze it possible anti-inflammatory properties in vitro. Total polyphenol content (with the Folin-Ciocalteau method) and antioxidant capacity (by FRAP and DPPH) were determined. Extracts inflammatory features were measured by NO and TNF- $\alpha$ release, and by TNF- $\alpha$ gene expression. Our results indicated that hydroalcoholic extracts present higher total polyphenol content $(p<0.001)$ and antioxidant capacity $(p<0.001$, by FRAP) than the aqueous ones. Furthermore, we report that hydroalcoholic leaves extract presented greater in vitro anti-inflammatory effect, especially the leave hydroalcoholic regarding NO release $(p<0.001$, against LPS treatment), aqueous and hydroalcoholics regarding TNF- $\alpha$ release $(p<0.05)$, and only the hydroalcoholic in the TNF- $\alpha$ gene expression $(p<0.01)$. In conclusion, the avocado hydroalcoholic extracts, and especially from leaves, present in vitro anti-inflammatory features that might be considered for human health improvement applications.
\end{abstract}

Keywords: Persea americana; Avocado; Antioxidant; Polyphenols; Anti-inflammatory features.

Resumen: Existe una tendencia mundial de incremento en prevalencia de enfermedades no transmisibles, que se caracterizan por un estado pro-inflamatorio crónico. Por lo tanto, es importante estudiar la relación entre alimentos y salud. La palta (Persea americana), sobresale en la industria por su valor nutricional. El procesamiento de la palta genera gran cantidad de subproductos, que contienen bioactivos con propiedades beneficiosas, como polifenoles. El objetivo del presente trabajo fue caracterizar cuatro extractos de palto (acuoso e hidroalcohólico; de hoja y de cáscara) y analizar sus posibles propiedades anti-inflamatorias in vitro. Fueron determinados polifenoles totales (con el método de Folin-Ciocalteau) y capacidad antioxidante (por FRAP y DPPH) de los extractos. Las propiedades antiinflamatorias de los extractos fueron determinadas por la liberación de NO y de TNF- $\alpha$, y por la expresión génica de TNF- $\alpha$. Los resultados indican que los extractos hidroalcohólicos presentan más polifenoles $(p<0,001)$ y capacidad antioxidante $(p<0,001$, por FRAP) que los acuosos. Mas aún, observamos que los extractos hidroalcohólicos de hojas presentaron mayores efectos anti-inflamatorios in vitro, especialmente el hidroalcohólico de hoja en liberación de NO ( $p<0,001$, frente a tratamiento con LPS), acuosos e hidroalcohólicos en liberación de TNF- $\alpha(p<0,05)$, y solo los hidroalcohólicos en la expresión de TNF- $\alpha(p<0,01)$. En conclusión, los extractos hidroalcohólicos de palto, y especialmente el de hoja, presentan propiedades anti-inflamatorias in vitro que pueden ser consideradas para aplicaciones en mejoría de salud humana.

Palabras clave: Persea americana; Palto; Antioxidante; Polifenoles; Capacidad anti-inflamatoria

Recibido | Received: November 8, 2019

Aceptado | Accepted: February 6, 2020

Aceptado en versión corregida | Accepted in revised form: March 27, 2020

Publicado en línea | Published online: July 30, 2020

Este artículo puede ser citado como / This article must be cited as: A Ovalle-Marin, C Parra-Ruiz, F Rivas, JF Orellana, DF Garcia-Diaz, P Jimenez. 2020. Characterization of Persea americana Mill. peels and leaves extracts and analysis of its potential in vitro anti-inflammatory properties. Bol Latinoam Caribe Plant Med Aromat 19 (4): 395 - 407. https://doi.org/10.37360/blacpma.20.19.4.27 


\section{INTRODUCTION}

During inflammatory processes, the release of proinflammatory mediators that are co-stimulated by signs of endogenous or exogenous origin are triggered. This phenomenon modifies the response of immune cells and can produce a clinic state termed systemic inflammatory response syndrome (BlancasFlores et al., 2010). The increased prevalence of noncommunicable diseases (NCDs) (WHO, 2010), which are characterized for present a systemic inflammatory state related with feeding, such as cardiovascular diseases, diabetes mellitus type 2, arterial hypertension and dyslipidemia, has led to a bigger and growing interest in studying the relationships between food properties and health (Araya et al., 2006).

Avocado (Persea americana), also known as aguacate, is a tropical American fruit native from Central America and Mexico. It is produced by an evergreen tree (15-20 $\mathrm{m}$ of height). Avocado it has been a staple dietary component for at least 9.000 years. The genus Persea (Clus.) Miller belongs to the family Lauraceae. Avocado is a specie with several taxa or subspecies, which include the Mexican ( $P$. americana var. drymifolia), West Indian or Antillean $(P$. americana var. americana) and Guatemalan $(P$. nubigena var. nubigena and $P$. nubigena var. guatemalensis) botanical varieties. Each variety presents typical characteristics in terms of leaves, fruits, flowering period, etc. In Chile, it grows from I to VII region, being the world's second largest avocado producer after Mexico (Bravo, 2010). Avocado fruit is rich in monounsaturated fatty acids (especially oleic acid), dietary fiber, vitamins B and E, and other nutrients (Wang et al., 2010). From all the avocado varieties, Persea americana Mill var. Hass, is the most consumed worldwide (USDA, 2011). Avocado consumption has been associated with several benefits for health, related to improved diet quality and nutrients intake, leading to lower risk of NCDs such as metabolic syndrome (Fulgoni et al., 2013; Tabeshpour et al., 2017).

In addition to the nutritional values of its fruits, the leaves and other morphological parts of avocado possess therapeutic properties, and are have been widely used for centuries in ancient cultures or folk medicine, generally as infusions (HurtadoFernandez et al., 2017), for their biological activities relating to control and/or treatment of anemia, diabetes mellitus, gastritis and bronchitis (Ross, 2001). In this context, leaves extract treatments have shown anti-hypertensive (Adeboye et al., 1999; Owolabi et al., 2005), hypoglycemic (Antia et al., 2005), analgesic and also anti-inflammatory effects (Adeyemi et al., 2002).

Peels and leaves contain several bioactive compounds, including polyphenols (Torres et al., 1987) such as procyanidins (Wang et al., 2010; Chavez et al., 2011; Kosinska et al., 2012), chlorogenic acid, quercetins (Kosinska et al., 2012), and epi(catechins) (Hirasawa et al., 2008; Chavez et al., 2011; Kosinska et al., 2012).

Wang et al. (2010), reported that peels and pulp from Hass avocado present higher content of polyphenols and antioxidant capacity related to other varieties studied. Similar results found Kosinska et al. (2012), regarding antioxidant capacity measured by TEAC, ORAC, DPPH and FRAP assays. Besides, Hass avocado variety shows the highest phenolic compounds content in its seed (64\%), followed by peels $(23 \%)$ and pulp (13\%). Therefore, by-products of avocado (leaves and peels) present upper antioxidant activity with respect to pulp (Wang et al., 2010) and other fruits already known by its high antioxidant capacity (Wu et al., 2004).

The avocado industrial processing generates by-products such as leaves (pruning) and peels, both without commercial value. According to the latter stated, these could be used as potential sources of natural antioxidants or functional food ingredients (Kosinska et al., 2012), thus generating new products, granting an added value to avocado industry (Wang et al., 2010). Therefore, the objective of the present study was to characterize and analyze the anti-inflammatory properties of aqueous and hydroalcoholic avocado (Persea americana Mill var. Hass) extracts from leaves and peels on an in vitro model.

\section{MATERIALS AND METHODS Avocado products}

Avocado ( $P$. americana cv. Hass) leaves were collected in January 2017 from farm located in Peñaflor (3335'35' latitude; 70 52'48', longitude), Valparaiso, Chile. Avocado peels were purchased from a supermarket in Santiago, Region Metropolitana, Chile.

\section{Preparation of avocado extracts var. Hass (aqueous} and hydroalcoholic) from leaves and peels

Separately, avocado leaves (50 g) and peels (60 g) were scalded at $95^{\circ} \mathrm{C}$ for $4 \mathrm{~min}$ and then cooled off 
quickly in a cold-water spurt. Then, samples were dried at $45^{\circ} \mathrm{C}$ for $18 \mathrm{~h}$ on an air forced oven (WTE, Germany) and stored in plastic bags at room temperature in the dark until extract preparation. Dry avocado leaves and peels were pulverized and macerated with ethanol/water (1:1). The prepared extracts were aqueous leaves (AL), aqueous peels (AP), hydroalcoholic leaves (HL) and hydroalcoholic peels (HP) extracts. In order to obtain the hydroalcoholic extracts (HL and HP, from 6,6 and $6,8 \mathrm{~g}$, respectively) or with water to obtain the aqueous extracts (AL and AP, from 5,5 and 5,2 g, respectively), all extracts were dryed for $72 \mathrm{~h}$ at room temperature. Then, the extract was separated by filtration. Finally, each extract was carried to a final volume of $250 \mathrm{~mL}$ and frozen at $-20^{\circ} \mathrm{C}$.

\section{Total polyphenol content of avocado extracts}

The total polyphenol content (TPC) was determined by Folin-Ciocalteau colorimetric method (Singleton et al., 1965) and expressed as $\mathrm{mg}$ of gallic acid equivalents (GAE) per gram of dry sample (DS), according to a calibration curve $\left(200-600 \mu \mathrm{g} \cdot \mathrm{mL}^{-1}\right.$, $\mathrm{R}^{2}$ : 0.993). All experiments were performed in triplicate.

\section{Measurement of the antioxidant activity of avocado extracts}

The antioxidant activity was carried out by 2,2diphenyl-1-picrylhydrazyl (DPPH) method (BrandWilliams et al., 1995) and Ferric reducing antioxidant power (FRAP) (Benzie et al., 1996), using a spectrophotometer (UV/Vis Lambda 25, Perkin Elmer, Cambridge, UK) at 517 and $593 \mathrm{~nm}$ respectively. Results were expressed as half maximal inhibitory concentration ( $\mathrm{IC}_{50}, \mathrm{mg}$ per gram of DS) for DPPH method and $\mathrm{mmol} \mathrm{Fe} \mathrm{F}^{+2}$ per $100 \mathrm{~g}$ of DS for FRAP. All experiments were performed in triplicate.

\section{HPLC-DAD analysis}

The analyses were conducted using an Agilent 1100 HPLC (Agilent Technologies Inc., USA) system coupled with an Esquire 4000 ion trap LC/MS system (Bruker Daltoniks, Germany), using a C18 column (5 $\mu \mathrm{m}, 4.6 \mathrm{~mm}$ i.d x $25 \mathrm{~cm}$, Spherisorb ODS-2, Waters, Ireland). The mobile phase was formic acid in water $(0.34 \% \mathrm{v} / \mathrm{v}$, solvent A) and acetonitrile (solvent B) at a flow rate of $1 \mathrm{~mL} / \mathrm{min}$ according to the following elution gradient: $0-3 \mathrm{~min}, 7.3 \% \mathrm{~B} ; 3-73,7.3 \% \mathrm{~B}$; 73-80 min, $35 \% \mathrm{~B}$; 80-85 min, $70 \% \mathrm{~B}$; $85-88 \mathrm{~min}$, $70 \% \mathrm{~B} ; 88-90 \mathrm{~min}, 7.3 \%$. The total analysis time was
$90 \mathrm{~min}$, and $5 \mathrm{~min}$ was required for reestablishing and equilibrating the initial conditions. Phenolic compounds were detected at $280 \mathrm{~nm}$. The mass spectral data were acquired in negative mode; ionization (nebulization) was performed with nitrogen as drying gas at $50 \mathrm{psi}, 365^{\circ} \mathrm{C}$ and at a flow rate of $10 \mathrm{~L} / \mathrm{min}$ and capillary voltage $3000 \mathrm{~V}$. All scans were performed in the range $50-1400 \mathrm{~m} / \mathrm{z}$. The trap parameters were set in ion charge control using manufacturer default parameters. Collision induced dissociation was performed by collisions with the helium background gas present in the trap. Fragmentation was set with Smart Frag.

\section{Cell culture}

All procedures were performed as previously described (Reyes-Farias et al., 2014). The mouse macrophage RAW264.7 cell line (obtained from the Laboratory of Biochemistry, Metabolism and Drug Resistance of Institute of Biomedical Science -ICBM- of University of Chile), was used. Cells were maintained at standard cell culture conditions $\left(37^{\circ} \mathrm{C}\right.$ in a humidified atmosphere containing $5 \%$ $\mathrm{CO}_{2}$ ) and were cultured in DMEM (Invitrogen, Paisley, UK) containing $4.5 \mathrm{~g} \cdot \mathrm{L}^{-1}$ glucose, $10 \%$ fetal bovine serum (Biological Industries, Beit Haemek,

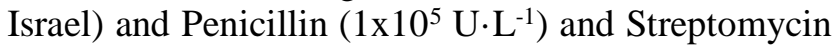
$\left(0,1 \mathrm{~g} \cdot \mathrm{L}^{-1}\right)$ antibiotics (Corning Life Sciences, USA). For experiments, cells were seeded at 70.000 cells. $\left[\mathrm{cm}^{2}\right]^{-1}$ in 12 -well plates. Macrophages were pre-treated with each extract at a $100 \mathrm{~mol} \cdot \mathrm{L}^{-1}$ [total polyphenols] for 1 hour, and then cultured with 5 $\mathrm{mg} \cdot \mathrm{L}^{-1}$ of lipopolysaccharide (LPS) (Sigma-Aldrich Chemical Co., Saint Louis, USA) for 24 hours. At the end of the trials, culture media were collected inflammatory response evaluation.

\section{Determination of secretion of inflammatory markers}

The amount of nitrite in cell-free culture supernatants was measured using Griess reagent according to the manufacturer's protocol (working range 0.43-65 $\mu \mathrm{M}$ nitrite) (Sigma-Aldrich, St. Louis, USA). Briefly, 50 $\mu \mathrm{L}$ of supernatant was mixed with an equivalent volume of the Griess reagent in a 96-well flat bottom plate. After a $30 \mathrm{~min}$ incubation in darkness, absorbance at $540 \mathrm{~nm}$ was measured using a NanoQuant InfiniteM200 PRO spectrophotometer (Tecan, Männedorf, Switzerland). The amount of nitrite was calculated from a $\mathrm{NaNO}_{2}$ standard curve. On the other hand, TNF- $\alpha$ secretion to culture media 
was measured using a MILLIPLEX MAP Mouse Adipokine Magnetic Bead Panel (Merck Millipore, Billerica, MA, USA), according to manufacturer's protocol. This determination was performed using Luminex xMAP technology (Merck Millipore) at the Department of Virology from the Institute of Biomedical Science (ICBM, University of Chile). Results were corrected by cell viability.

\section{Lactate Dehydrogenase assay}

Cellular viability was determined according to the activity of lactate dehydrogenase (LDH) enzyme according to a commercial kit (Cayman Chemical Company, Ann Arbor, USA).

\section{Gene expression assay}

All procedures were as previously described with modifications (Reyes-Farias et al., 2014). Total RNA was isolated from samples using Trizol (Invitrogen, Paisley, United Kingdom), according to the supplier's protocol. Purified RNA was then treated with DNase (DNAfree kit; Ambion, Austin, USA) and used to generate first-strand cDNA with the High-Capacity cDNA Reverse Transcription Kit (Applied Biosystems, Foster City, USA). The resultant cDNA was amplified with a specific probe for mouse TNF- $\alpha$ (Mn0044326061) in a total volume of $10 \mu \mathrm{L}$. Real-time PCR was performed in a Stratagene Mx3000P System (Agilent Technologies) following the manufacturer's recommendations (Applied Biosystems, Foster City, USA). The expression levels of the target gene studied was normalized by the expression of Cyclophilin A (Mn0232430) as the selected internal control (also supplied by Applied Biosystems). Fold change between groups was calculated by the $2^{-\Delta \Delta \mathrm{CT}}$ method.

\section{Statistical analyses}

Statistical analysis was performed by one-way analysis of variance (one-way ANOVA) followed by Student-Newman-Keuls's post hoc test, and by twoway ANOVA. The results are expressed as mean \pm standard deviation (SD). Differences were considered statistically significant at the $p<0.05$ level. Software GraphPad Prism version 6.0 was used for data analysis (GraphPad Prism Inc., San Diego, USA).

\section{RESULTS}

\section{Characterization of avocado extracts}

Table No. 1 shows the total polyphenols content (TPC) and antioxidant activity (DPPH and FRAP) of avocado extracts (AL, AP, HL and HP) studied. Highest TPC were observed in hydroalcoholic extracts than in aqueous ones $(p<0.001)$. Among leaves and peels, higher TPC content was found in the latter $(p<0.01$ on aqueous extracts, $p<0.001$ on hydroalcoholic extracts). The antioxidant capacity measured by DPPH assay is inversely proportional to the value of $\mathrm{IC}_{50}$, since the higher the antioxidant capacity of the extract, the lower concentration it is required to stabilize the radical DPPH. According to this methodology, the hydroalcoholic extracts showed higher antioxidant capacity than the aqueous extracts, and among the latter, peels extract showed the lower $\mathrm{IC}_{50}$ values $(p<0.001$ on peels between AP and HP). Finally, the antioxidant capacity measured by FRAP assay showed similar results than the ones obtain by DPPH, but even more higher antioxidant activity on hydroalcoholic extracts $(p<0.01)$. Finally, Tables 1S-4S and Figures 1S-4S (supplementary files) shows the identification of phenolic compounds of $\mathrm{AP}, \mathrm{AL}, \mathrm{HP}$ and $\mathrm{HL}$, respectively.

Table No. 1

Total phenolic content and antioxidant capacity of avocado extracts

Total polyphenolic content Antioxidant activity

Folin-Ciocalteau DPPH FRAP

[mg GAE per gram of DS]

\begin{tabular}{lccc} 
& {$[\mathrm{mg}$ GAE per gram of DS $]$} & {$\left[\mathrm{IC}_{50}:\right.$ mg per gram of DS $]$} & {$\left[\mathrm{mmol} \mathrm{Fe}^{+2}\right.$ per $100 \mathrm{~g}$ of DS] } \\
\hline $\mathrm{AL}$ & $36.03 \pm 0.18^{\mathbf{a}}$ & $3.07 \pm 0.27^{\mathbf{b}}$ & $10.46 \pm 0.00^{\mathbf{a}}$ \\
$\mathrm{AP}$ & $51.60 \pm 0.06^{\mathbf{b}}$ & $4.35 \pm 0.16^{\mathbf{c}}$ & $11.59 \pm 0.02^{\mathbf{a}}$ \\
$\mathrm{HL}$ & $69.09 \pm 0.87^{\mathbf{c}}$ & $2.30 \pm 0.30^{\mathbf{a b}}$ & $20.61 \pm 1.14^{\mathbf{b}}$ \\
$\mathrm{HP}$ & $75.52 \pm 0.98^{\mathbf{d}}$ & $1.73 \pm 0.15^{\mathbf{a}}$ & $18.33 \pm 0.18^{\mathbf{b}}$ \\
\hline
\end{tabular}

AL: aqueous leaves extract; AP: aqueous peel extract; HL: hydroalcoholic leaves extract; HP: hydroalcoholic peel extract; $n=2$; Mean value within each group with different letters (a, b, $c$ and d) indicated significant difference at $p<0.05$. GAE: Gallic Acid Equivalents; DS: Dry Sample 


\section{Inflammatory response induced by LPS}

The pretreatment of macrophages with AL extract $(p<0.01)$, and not with AP, inhibited the release of NO regarding the response induced by LPS (Figure No. 1). HP increased $(p<0.001)$ and HL reduced $(p<0.01)$ significantly the NO release when compared to LPS only treated cells. On the other hand, TNF- $\alpha$ gene expression was significantly increased by the LPS treatment $(p<0.05)$, being this effect partially prevented by the treatment with all the extracts tested (Figure No. 2A). No differences were observed regarding TNF- $\alpha$ protein release (Figure No. 2B). In order to determine if there is a relationship among the type of extraction used and the type of avocado byproduct in all the variables analyzed, we performed two-way ANOVA. We observed a significant effect of the by-product used $(p<0.001)$ and also an interaction between both factors $(p<0.001)$. Thus, we grouped and plot data in terms of type of extraction (hydroalcoholic or aqueous) and by-product (peel or leaves) (Figure No. 3). It was observed a higher antiinflammatory effect of hydroalcoholic extracts (HA), regarding TNF- $\alpha$ gene expression $(p<0.01)$ (Figure No. $3 \mathrm{~B}$ ), and from both types of extraction regarding TNF- $\alpha$ secretion $(p<0.05)$ (Figure No. 3C). Finally, it was observed an anti-inflammatory effect of leaves extracts $(\mathrm{LV})$, regarding NO release $(p<0.01)$ (Figure No. 3D) and a mild effect from both types of byproducts extracts on TNF- $\alpha$ gene expression $(p<0.05)$ (Figure No. 3E).
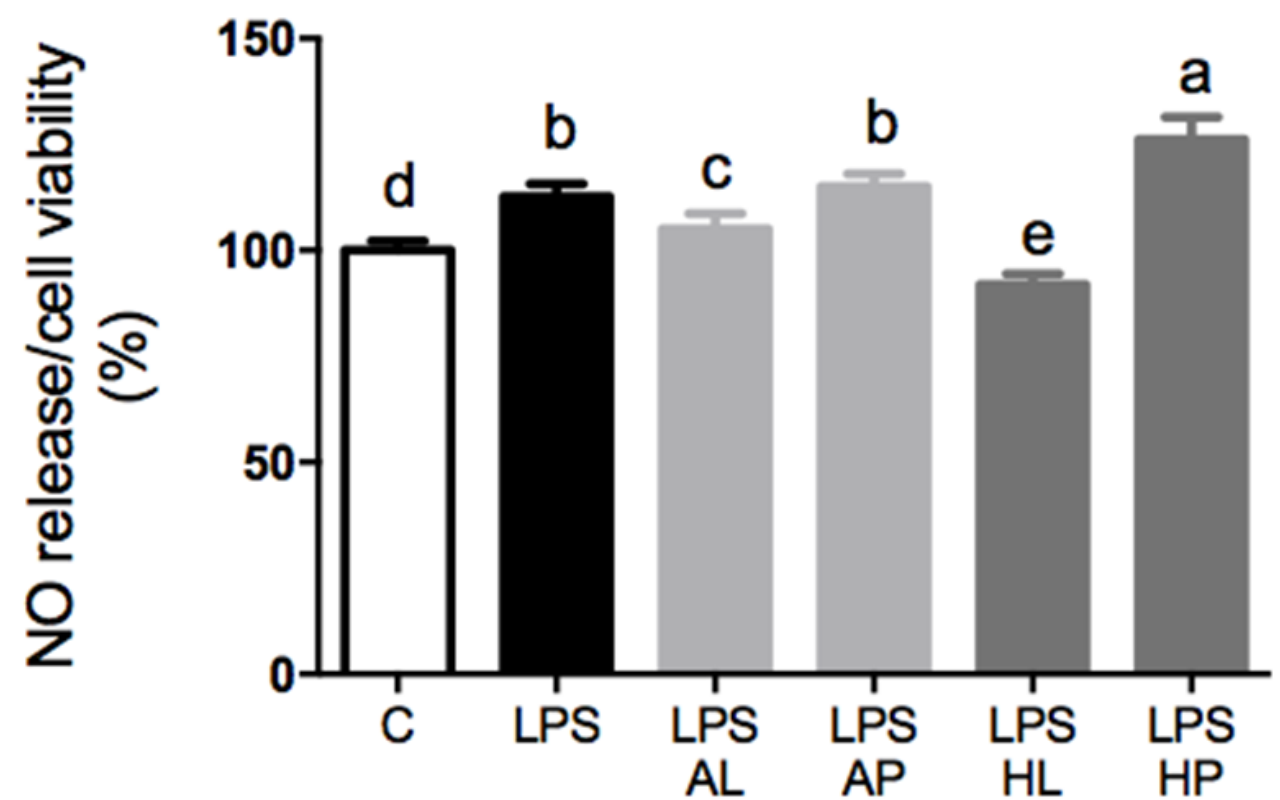

Figure No. 1

Percentage of nitric oxide release from activated mouse macrophages corrected for the percentage of cell viability. Macrophages were pre-treated with each extract $100 \mathrm{~mol} \cdot \mathrm{L}-1$ [total polyphenols] for 1 hour, and then activated with $5 \mathrm{mg} \cdot \mathrm{L}-1$ of LPS for 24 hours. Values $(\mathrm{n}=4)$ were expressed as mean \pm SD. One-way ANOVA followed by Student-Newman-Keuls's post hoc test was performed to determinate statistical differences among groups. NO, nitric oxide; LPS, lipopolysaccharide; AL, aqueous leaves extract; AP, aqueous peel extract; HL, hydroalcoholic leaves extract; HP, hydroalcoholic peel extract. Different letters meant statistical significance of at least $p<0.05$. 
A

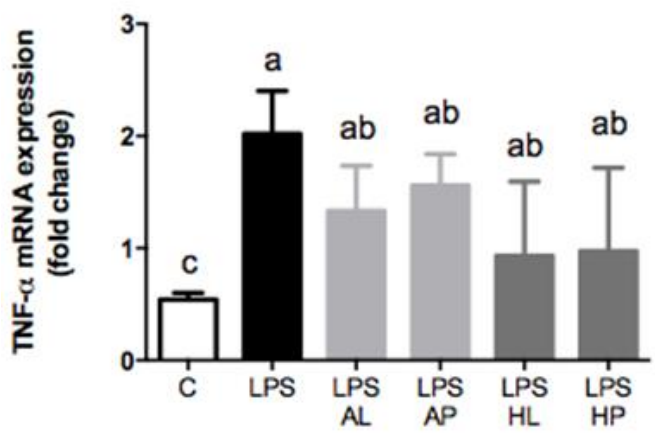

B

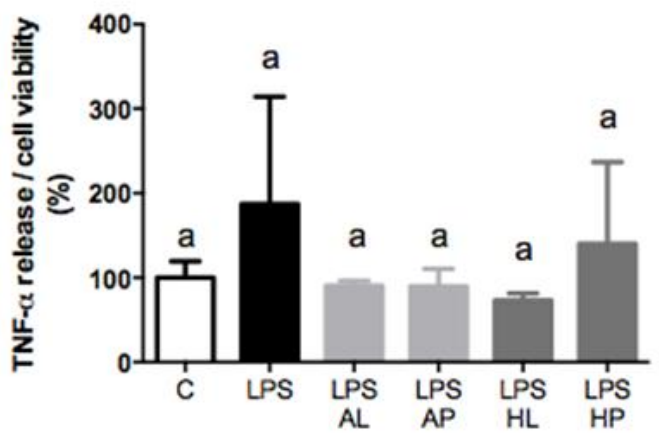

Figure No. 2

(A) TNF- $\alpha$ gene expression and (B) protein release, by activated macrophages. Macrophages were pretreated with each extract $100 \mathrm{~mol} \cdot \mathrm{L}^{-1}$ [total polyphenols] for 1 hour, and then activated with $5 \mathrm{mg} \cdot \mathrm{L}^{-1}$ of LPS for 24 hours. Values $(n=4)$ were expressed as mean \pm SD. One-way ANOVA followed by Student-Newman-Keuls's post hoc test was performed to determinate statistical differences among groups. NO, nitric oxide; LPS, lipopolysaccharide; AL, aqueous leaves extract; AP, aqueous peel extract; HL, hydroalcoholic leaves extract; HP, hydroalcoholic peel extract.

Different letters meant statistical significance of at least $p<0.05$.
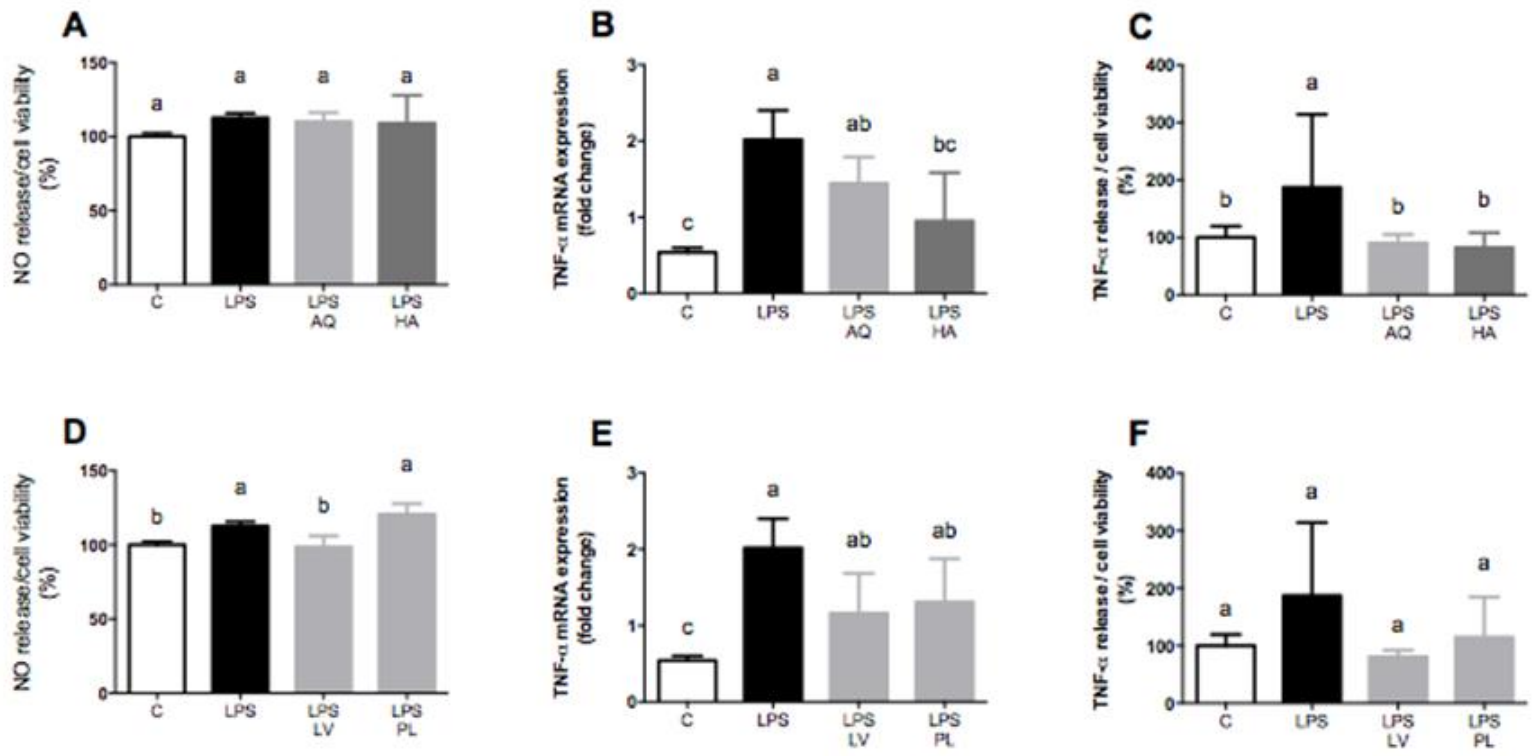

Figure No. 3

Data analysis for NO release, TNF- $\alpha$ gene expression and TNF- $\alpha$ protein grouped by type of extraction (A, B and $\mathrm{C}$; respectively), and by type of by-product (D, E and F, respectively). Macrophages were pre-treated with each extract $100 \mathrm{~mol} \cdot \mathrm{L}^{-1}$ [total polyphenols] for $1 \mathrm{hour}$, and then activated with $5 \mathrm{mg} \cdot \mathrm{L}^{-1} \mathrm{of}$ LPS for 24 hours. Values $(n=4)$ were expressed as mean \pm SD. One-way ANOVA followed by Student-Newman-Keuls's post hoc test was performed to determinate statistical differences among groups. NO, nitric oxide; LPS, lipopolysaccharide; AQ, aqueous extracts; HA, hydroalcoholic extracts; LV, leaves extracts; PL, peel extracts. Different letters meant statistical significance of at least $p<0.05$. 


\section{DISCUSSION}

Avocado by-products have been described to present elevated content of antioxidant molecules, and also, its consumption have been related to better health outcomes. In the present article we aimed to evaluate the possible anti-inflammatory effects of these raw material.

Hydroalcoholic extracts (especially HP), presented total phenolic content significantly higher than aqueous extracts. These differences could be attributed to avocado by-products per se (chemical nature of phenolic compounds) and the polarity of solvents used (Naczk et al., 2006). Alothman et al. (2009) and Turkmen et al. (2006), reported in tea and some fruits that $50 \%$ ethanol-water mix takes advantage over the phenolic compounds extraction by aqueous solvent, being this reflected in an increase of the total polyphenol content. In the present study, total polyphenol content in peels extracts were higher than those reported by Wang et al. (2010), (12,6 mg GAE/g, respectively), but similar to those described by Chávez et al. (2011), (32,93 to 89,97 mg GAE/g dry matter). Regarding leaves extracts, Torres et al. (1987), found contents of 17,50 to $19,30 \mathrm{GAE} \mathrm{mg/g}$, expressed as fresh weight, in young and mature leaves of Hass variety, being this value lower than the ones observed here. The differences with other authors could be explained by cultivar differences, geographical location, collecting period, extraction method, avocado by-products type (peels or leaves), among others.

As well as in TPC, hydroalcoholic extracts showed the highest antioxidant activity, determined by DPPH and FRAP assays. This activity is higher than those reported for pulp extracts in previous studies (Wang et al., 2010). Therefore, it is possible to postulate peels and leaves of this specie as candidates for further investigation regarding disease prevention with a strong oxidative and inflammatory component, such as NCDs. However, it is worth to mention that no differences were observed between peels and leaves extracts, among aqueous and hydroalcoholic extracts. Thus, a differential biological effect by its application could be ascribed to differential compound content. Adeyemi et al. (2002), reported anti-inflammatory activity of aqueous extracts from fresh leaves of Persea americana on an in vivo model with induced subplantar tissue inflammation. Thus, as a first approximation, we studied the anti-inflammatory effect from avocado extracts over an inflammation cell model composed by macrophages activated with LPS. We observed that, overall, hydroalcoholic rather than aqueous and leaves rather than peel extracts presented higher anti-inflammatory features. The outcome regarding hydroalcoholic extracts is easy to explain taking into account the polarity of the extraction. The outcome related to type of by-product could be explained by a possible differential composition of compounds in each extract that could have an influence in a biological function basis. Torres et al. (2014), evaluated the potential pest control of avocado peels, seed and pulp extracts. These authors found that seed, followed closely by peels extracts, present high larvicidal activity. They described in a seed ethanol extract the presence of alkaloids, tannins, saponins, unsaturated steroids and triterpenoids, 2-deoxysugars, flavonoids (leucoanthocyanins), fats and oils. Perhaps the peels present some compounds at high concentration that were extracted only in water: ethanol condition, which present pro-inflammatory features (e.g. saponins). Moreover, we observed that hydroalcoholic peels extracts present mainly procyanidins dimers and trimers, and hydroalcoholic leaves extracts present procyanidins trimers and also chlorogenic acid (supplementary data). In this sense, procyanidin dimers and trimers have been reported to impair the inflammatory response in human monocytes (Terra $e t$ al., 2011). However, procyanidins trimers have been observed to induce higher NO release by rat aortic endothelial cells (Byun et al., 2012), and even to activate murine macrophages (Sung et al., 2013). Moreover, it has been described that procyanidins monomers and dimers from a french maritime pine bark extract repressed the expression of several antiinflammatory markers (NO, TNF- $\alpha$ and others), whereas a specific trimer (C2), enhanced these variables in murine macrophages (Park et al., 2000). On the other hand, the anti-inflammatory effects of chlorogenic acids have been clearly established before (Liang et al., 2016). In fact, it has been reported a strong anti-inflammatory activity over LPS-induced RAW264.7 macrophages, inhibiting the production of NO, IL-1, TNF- $\alpha$ and the expression of COX-2 and iNOS (Hwang et al., 2014). Thus, it would be expected an enhanced anti-inflammatory response in extracts that present this compound.

\section{CONCLUSIONS}

In conclusion, the avocado hydroalcoholic extracts, especially from leaves, present interesting in vitro 
anti-inflammatory features that might be considered for human health improvement applications. Thus, the next research step could encompass the study of avocado by-products in greater detail (with special attention in leaves) over different pathological models, in which inflammation plays a central role, in order to evaluate and verify the anti-inflammatory effect here reported. Therefore, could be of value to get a more detailed characterization of polyphenols from these extracts, in order to determine which of them are responsible for the antioxidant and antiinflammatory response observed, the evaluation of possible synergy, and the optimal doses and routes of administration to enhance health benefits.

\section{ACKNOWLEDGEMENTS}

The authors are thankful of Dr. Juan Diego Maya (Laboratory of Biochemistry, Metabolism and Drug Resistance, ICBM, University of Chile) for kindly facilitate RAW264.7 vials. This work was part of Grant $\mathrm{N}^{\circ} 11130373$ from The National Fund for Scientific and Technological Development (Fondecyt, Chile).

\section{REFERENCES}

Adeboye J, Fajonyomi M, Makinde J, Taiwo O. 1999. A preliminary study on the hypotensive activity of Persea americana leaf extracts in anaesthetized normotensive rats. Fitoterapia 70: 15 - 20.

https://doi.org/10.1016/s0367-326x(98)00015-x

Adeyemi OO, Okpo SO, Ogunti OO. 2002. Analgesic and anti-inflammatory effects of the aqueous extract of leaves of Persea americana Mill (Lauraceae). Fitoterapia 73: 375 - 380.

https://doi.org/10.1016/s0367-326x(02)00118-1

Alothman M, Bhat R, Karim AA. 2009. Antioxidant capacity and phenolic content of selected tropical fruits from Malaysia, extracted with different solvents. Food Chem 115: 785 - 788.

https://doi.org/10.1016/j.foodchem.2008.12.005

Antia B, Okokon J, Okon P. 2005. Hypoglycemic activity of aqueous leaf extract of Persea americana Mill. Ind J Pharmacol 37: 325 - 326. https://doi.org/10.4103/0253-7613.16858

Araya H, Clavijo C, Herrera C. 2006. Antioxidant capacity of fruits and vegetables cultivated in Chile. Arch Latinoam Nutr 56: 361 - 365.

Benzie IF, Strain JJ. 1996. The ferric reducing ability of plasma (FRAP) as a measure of "antioxidant power": the FRAP assay. Anal Biochem 239: 70 - 76. https://doi.org/10.1006/abio.1996.0292

Blancas-Flores G, Almanza-Perez J, Lopez-Roa R, Alarcon-Aguilar F, Garcia-Macedo R, Cruz M. 2010. Obesity as an inflammatory process. Bol Med Hosp Infant Mex 67: 88 - 97.

Brand-Williams W, Cuvelier ME, Berset C. 1995. Use of a free-radical method to evaluate antioxidant activity. Food Sci Technol 28: 25 - 30. https://doi.org/10.1016/s0023-6438(95)80008-5

Bravo J. 2010. El mercado de las paltas ODEPA. http://www.odepa.gob.cl/odepaweb/publicaciones/doc/2206.pdf

Byun EB, Ishikawa T, Suyama A, Kono M, Nakashima S, Kanda T, Miyamoto T, Matsui T. 2012. A procyanidin trimer, C1, promotes NO production in rat aortic endothelial cells via both hyperpolarization and PI3K/Akt pathways. Eur J Pharmacol 692: 52 - 60. https://doi.org/10.1016/j.ejphar.2012.07.011

Chavez F, Aranda M, Garcia A, Pastene E. 2011. Antioxidant polyphenols extracted from Avocado epicarp (Persea americana var. Hass) inhibit Helicobacter pylori urease. Bol Latinoam Caribe Plant Med Aromat 10: $265-280$.

Fulgoni VL, Dreher M, Davenport AJ. 2013. Avocado consumption is associated with better diet quality and nutrient intake, and lower metabolic syndrome risk in US adults: results from the National Health and Nutrition Examination Survey (NHANES) 2001-2008. Nutr J 12: 1 - 6.

https://doi.org/10.1186/1475-2891-12-1

Hirasawa M, Shimura K, Shimizu A, Mura K, Tokue C, Arai S. 2008. Quantification and functional analysis of dietary fiber and polyphenols in avocado. J Jap Soc Food Sci Technol 55: 95 - 101.

https://doi.org/10.3136/nskkk.55.95

Hurtado-Fernandez E, Fernandez-Gutierrez A, Carrasco-Pancorbo A. 2017. Avocado fruit exotic fruits reference guide. S. Rodrigues, E. Silva and E. de Brito, Academic Press. https://doi.org/10.1016/B978-0-12-803138-4.00001-0 
Hwang SJ, Kim YW, Park Y, Lee HJ, Kim KW. 2014. Anti-inflammatory effects of chlorogenic acid in lipopolysaccharide-stimulated RAW 264.7 cells. Inflamm Res 63: 81 - 90. https://doi.org/10.1007/s00011-013-0674-4

Kosinska A, Karamac M, Estrella I, Hernandez T, Bartolome B, Dykes GA. 2012. Phenolic compound profiles and antioxidant capacity of Persea americana Mill. peels and seeds of two varieties. J Agric Food Chem 60: 4613 - 4619. https://doi.org/10.1021/jf300090p

Liang N, Kitts DD. 2016. Role of chlorogenic acids in controlling oxidative and inflammatory stress conditions. Nutrients 8 (1). https://doi.org/10.3390/nu8010016

Naczk M, Shahidi F. 2006. Phenolics in cereals, fruits and vegetables: occurrence, extraction and analysis. J Pharm Biomed Anal 41: 1523 - 1542. https://doi.org/10.1016/j.jpba.2006.04.002

Owolabi MA, Jaja SI, Coker HA. 2005. Vasorelaxant action of aqueous extract of the leaves of Persea americana on isolated thoracic rat aorta. Fitoterapia 76: 567 - 573. https://doi.org/10.1016/j.fitote.2005.04.020

Park YC, Rimbach G, Saliou C, Valacchi G, Packer L. 2000. Activity of monomeric, dimeric, and trimeric flavonoids on NO production, TNF-alpha secretion, and NF-kappaB-dependent gene expression in RAW 264.7 macrophages. FEBS Lett 465: 93 - 97. https://doi.org/10.1016/s0014-5793(99)01735-4

Reyes-Farias M, Vasquez K, Ovalle-Marin A, Fuentes F, Parra C, Quitral V, Jimenez P, Garcia-Diaz DF. 2014. Chilean native fruit extracts inhibit inflammation linked to the pathogenic interaction between adipocytes and macrophages. J Med Food 18: 601 - 608. https://doi.org/10.1089/jmf.2014.0031

Ross I. 2001. Medicinal plants of the world, Springer Nature, Switzerland

Singleton V, Rossi J. 1965. Colorimetry of total phenolics with phosphomolybdic-phosphotungstic acid reagents. Am J Enol Viticult 16: 144 - 158.

Sung NY, Yang MS, Song DS, Byun EB, Kim JK, Park JH, Song BS, Lee JW, Park SH, Park HJ, Byun MW, Byun EH, Kim JH. 2013. The procyanidin trimer C1 induces macrophage activation via NF-kappaB and MAPK pathways, leading to Th1 polarization in murine splenocytes. Eur J Pharmacol 714: 218 - 228. https://doi.org/10.1016/j.ejphar.2013.02.059

Tabeshpour J, Razavi BM, Hosseinzadeh H. 2017. Effects of avocado (Persea americana) on metabolic syndrome: A comprehensive systematic review. Phytother Res 31: 819 - 837. https://doi.org/10.1002/ptr.5805

Terra X, Palozza P, Fernandez-Larrea J, Ardevol A, Blade C, Pujadas G, Salvado J, Arola L, Blay MT. 2011. Procyanidin dimer B1 and trimer $\mathrm{C} 1$ impair inflammatory response signalling in human monocytes. Free Radic Res 45: 611 - 619. https://doi.org/10.3109/10715762.2011.564165

Torres A, Mau-Lastovicks T, Rezaaiyan R. 1987. Total phenolics and highperformance liquid chromatography of phenolic acids of avocado. J Agric Food Chem 35: 921 - 925. https://doi.org/10.1021/jf00078a018

Torres RC, Garbo AG, Walde RZ. 2014. Larvicidal activity of Persea americana Mill. against Aedes aegypti. Asian Pac J Trop Med 7S1: S167 - S170. https://doi.org/10.1016/S1995-7645(14)60225-X

Turkmen N, Sari F, Velioglu YS. 2006. Effects of extraction solvents on concentration and antioxidant activity of black and black mate tea polyphenols determined by ferrous tartrate and Folin-Ciocalteu methods. Food Chem 99: 835 - 841. https://doi.org/10.1016/j.foodchem.2005.08.034

USDA. 2011. Avocado, almond, pistachio and walnut composition. Nutrient Data Laboratory. USDA National Nutrient Database for Standard Reference, Release 24. Washington, USA.

Wang W, Bostic TR, Gu LW. 2010. Antioxidant capacities, procyanidins and pigments in avocados of different strains and cultivars. Food Chem 122: 1193 - 1198. https://doi.org/10.1016/j.foodchem.2010.03.114

WHO. 2010. Global status report on noncommunicable diseases. WHO (World Health Organization), WHO Library Cataloguing-in-Publication Data.

Wu X, Beecher GR, Holden JM, Haytowitz DB, Gebhardt SE, Prior RL. 2004. Lipophilic and hydrophilic antioxidant capacities of common foods in the United States. J Agric Food Chem 52: 4026 - 4037. https://doi.org/10.1021/jf049696w 


\section{SUPPLEMENTARY MATERIAL}

Table No. 1S

Identification of phenolic compounds of aqueous peel extract (AP) by LC-MS

\begin{tabular}{|c|c|c|c|c|}
\hline Peak & Precursor $\mathrm{m} / \mathrm{z}[\mathrm{M}+\mathrm{H}]^{+}$ & Compound & Precursor m/z [M+H] & Compound \\
\hline \multirow[t]{2}{*}{17} & 867.2 & B-type procyanidin dimer & 865.5 & $\begin{array}{c}\text { B-type procyanidin } \\
\text { dimer }\end{array}$ \\
\hline & & & 353.1 & Caffeoylquinic acid \\
\hline \multirow[t]{2}{*}{19} & 578.9 & B-type procyanidin dimer & 577.3 & $\begin{array}{c}\text { B-type procyanidin } \\
\text { dimer }\end{array}$ \\
\hline & & & 449.7 & Eriodictyol-O-hexoside \\
\hline 21 & 577.8 & A-type procyanidin dimer & 289.2 & Epicatechin \\
\hline \multirow[t]{2}{*}{24} & 867.2 & B-type procyanidin trimer & 865.5 & $\begin{array}{c}\text { B-type procyanidin } \\
\text { trimer }\end{array}$ \\
\hline & & & 561.7 & $\begin{array}{l}\text { (Epi)afzelechin- } \\
\text { (epi)catechin }\end{array}$ \\
\hline \multirow[t]{2}{*}{25} & 866.5 & B-type procyanidin trimer & 865.1 & $\begin{array}{c}\text { B-type procyanidin } \\
\text { trimer }\end{array}$ \\
\hline & 578.3 & B-type procyanidin dimer & & \\
\hline
\end{tabular}

Table No. 2S

Identification of phenolic compounds of aqueous leaves extract (AL) by LC-MS

\begin{tabular}{|c|c|c|c|c|}
\hline Peak & $\begin{array}{c}\text { Precursor } \mathrm{m} / \mathrm{z} \\
{[\mathrm{M}+\mathrm{H}]^{+}}\end{array}$ & Compound & $\begin{array}{c}\text { Precursor } \mathrm{m} / \mathrm{z} \\
{[\mathrm{M}+\mathrm{H}]^{-}}\end{array}$ & Compound \\
\hline 5 & \multirow{3}{*}{579.1} & \multirow{3}{*}{$\begin{array}{l}\text { B-type procyanidin } \\
\text { dimer }\end{array}$} & 353.3 & Caffeoylquinic acid \\
\hline \multirow[t]{2}{*}{15} & & & 577.2 & $\begin{array}{c}\text { B-type procyanidin } \\
\text { dimer }\end{array}$ \\
\hline & & & 353.1 & Chlorogenic acid \\
\hline
\end{tabular}

Table No. 3S

Identification of phenolic compounds of hydroalcoholic peel extract (HP) extract by LC-MS

\begin{tabular}{ccccc}
\hline Peak & Precursor $\mathrm{m} / \mathrm{z}[\mathrm{M}+\mathrm{H}]+$ & Compound & Precursor $\mathrm{m} / \mathrm{z}[\mathrm{M}+\mathrm{H}]-$ & Compound \\
\hline 15 & 578.8 & B-type procyanidin dimer & 577.4 & B-type procyanidin dimer \\
& & & 353.1 & $\begin{array}{c}\text { Chlorogenic acid } \\
17\end{array}$ \\
& 579.0 & B-type procyanidin dimer & 577.3 & $\begin{array}{c}\text { B-type procyanidin dimer } \\
\text { eriodictyol -O- hexoside } \\
\text { Epicatechin }\end{array}$ \\
19 & 866.9 & B-type procyanidin dimer & 289.2 & B-type procyanidin trimer \\
21 & 449.8 & Kaempferol-O-hexoside & & B-type procyanidin trimer \\
& 867.1 & B-type procyanidin trimer & 867.1 & B-type procyanidin dimer \\
\hline
\end{tabular}


Table No. 4S

Identification of phenolic compounds of hydroalcoholic leaves extract (HL) by LC-MS

\begin{tabular}{|c|c|c|c|c|}
\hline Peak & Precursor m/z [M+H]+ & Compound & Precursor m/z [M+H]- & Compound \\
\hline 6 & & & 190.5 & caffeoylquinic acid \\
\hline \multirow[t]{2}{*}{14} & 577.9 & $\begin{array}{l}\text { B-type procyanidin } \\
\text { dimer }\end{array}$ & 706.8 & $\begin{array}{c}\text { Dicaffeoylquinic acid } \\
\text { dimer }\end{array}$ \\
\hline & & & 577.2 & $\begin{array}{l}\text { B-type procyanidin } \\
\text { dimer }\end{array}$ \\
\hline \multirow[t]{2}{*}{15} & 867.1 & $\begin{array}{l}\text { B-type procyanidin } \\
\text { trimer }\end{array}$ & 352.8 & $\begin{array}{c}\text { caffeoylquinic acid } \\
\text { dimer }\end{array}$ \\
\hline & & & 190.5 & caffeoylquinic acid \\
\hline 18 & 578.8 & $\begin{array}{l}\text { B-type procyanidin } \\
\text { dimer }\end{array}$ & 577.3 & $\begin{array}{l}\text { B-type procyanidin } \\
\text { dimer }\end{array}$ \\
\hline 21 & 866.4 & $\begin{array}{l}\text { B-type procyanidin } \\
\text { trimer }\end{array}$ & & \\
\hline \multirow[t]{2}{*}{25} & & & 865.6 & $\begin{array}{l}\text { B-type procyanidin } \\
\text { trimer }\end{array}$ \\
\hline & & & 561.7 & $\begin{array}{l}\text { Dímero } \\
\text { (epi)afzelequina- } \\
\text { (epi)catequina }\end{array}$ \\
\hline 31 & 627.0 & Quercetin-O-dihexoside & 625.5 & Quercetin-O-dihexoside \\
\hline 41 & 479.0 & $\begin{array}{l}\text { Quercetin-O- } \\
\text { glucuronide }\end{array}$ & 477.1 & $\begin{array}{l}\text { Quercetin-O- } \\
\text { glucuronide }\end{array}$ \\
\hline \multirow[t]{2}{*}{42} & 464.9 & Quercetin-O-hexoside & 515.2 & Dicaffeoylquinic acid \\
\hline & & & 463.3 & Quercetin-O-hexoside \\
\hline
\end{tabular}


Figure No. 1S

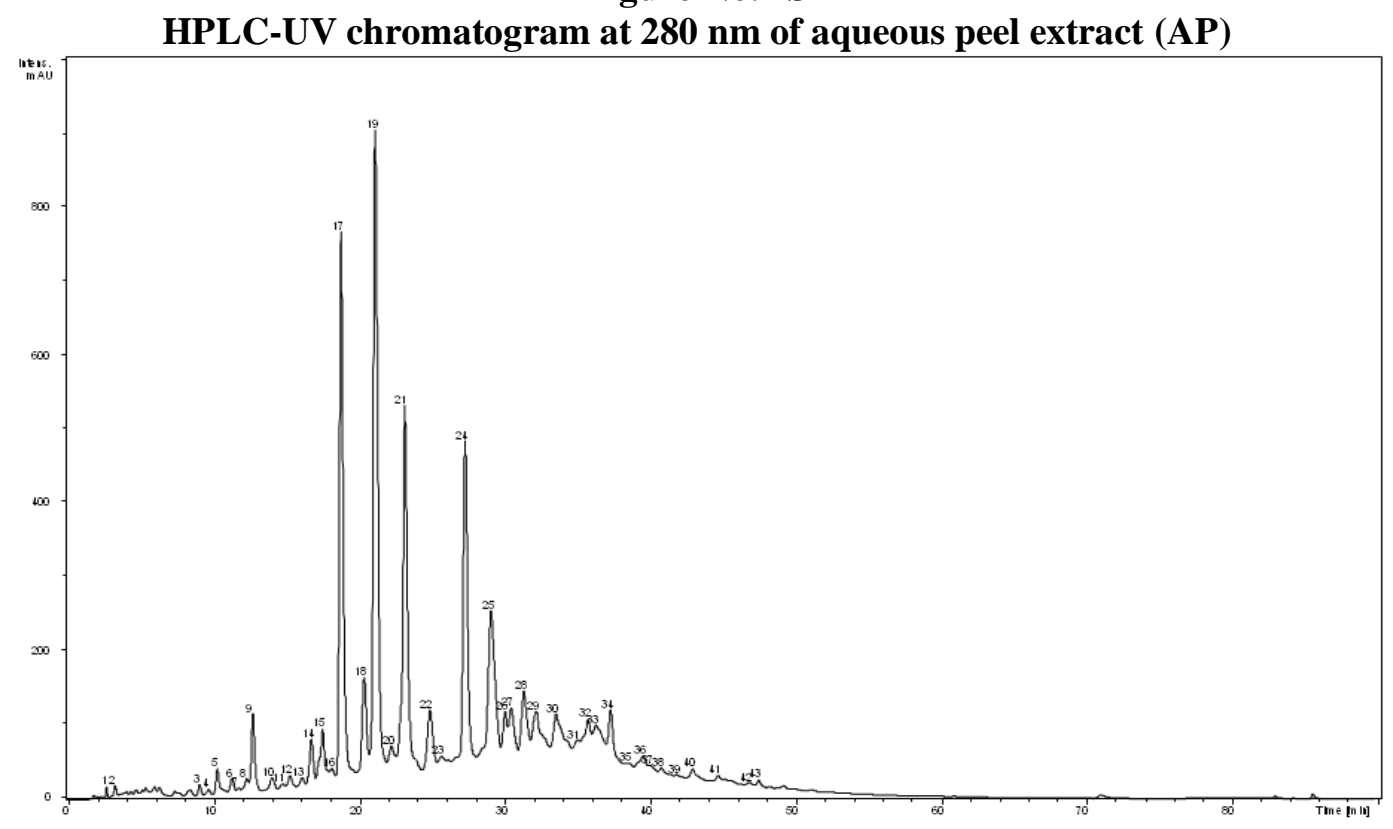

Figure No. 2S

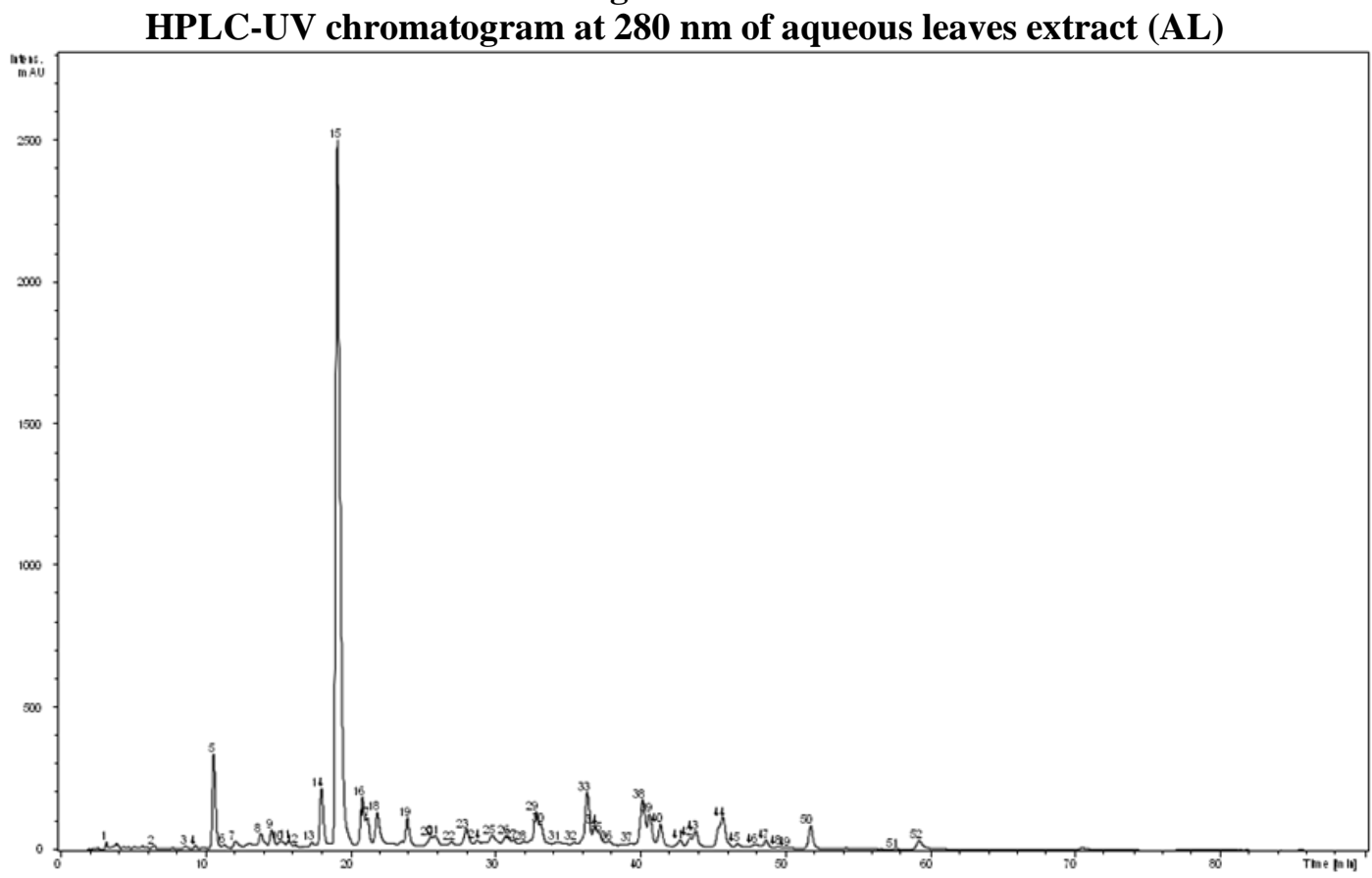

Boletín Latinoamericano y del Caribe de Plantas Medicinales y Aromáticas/406 
Figure No. 3S

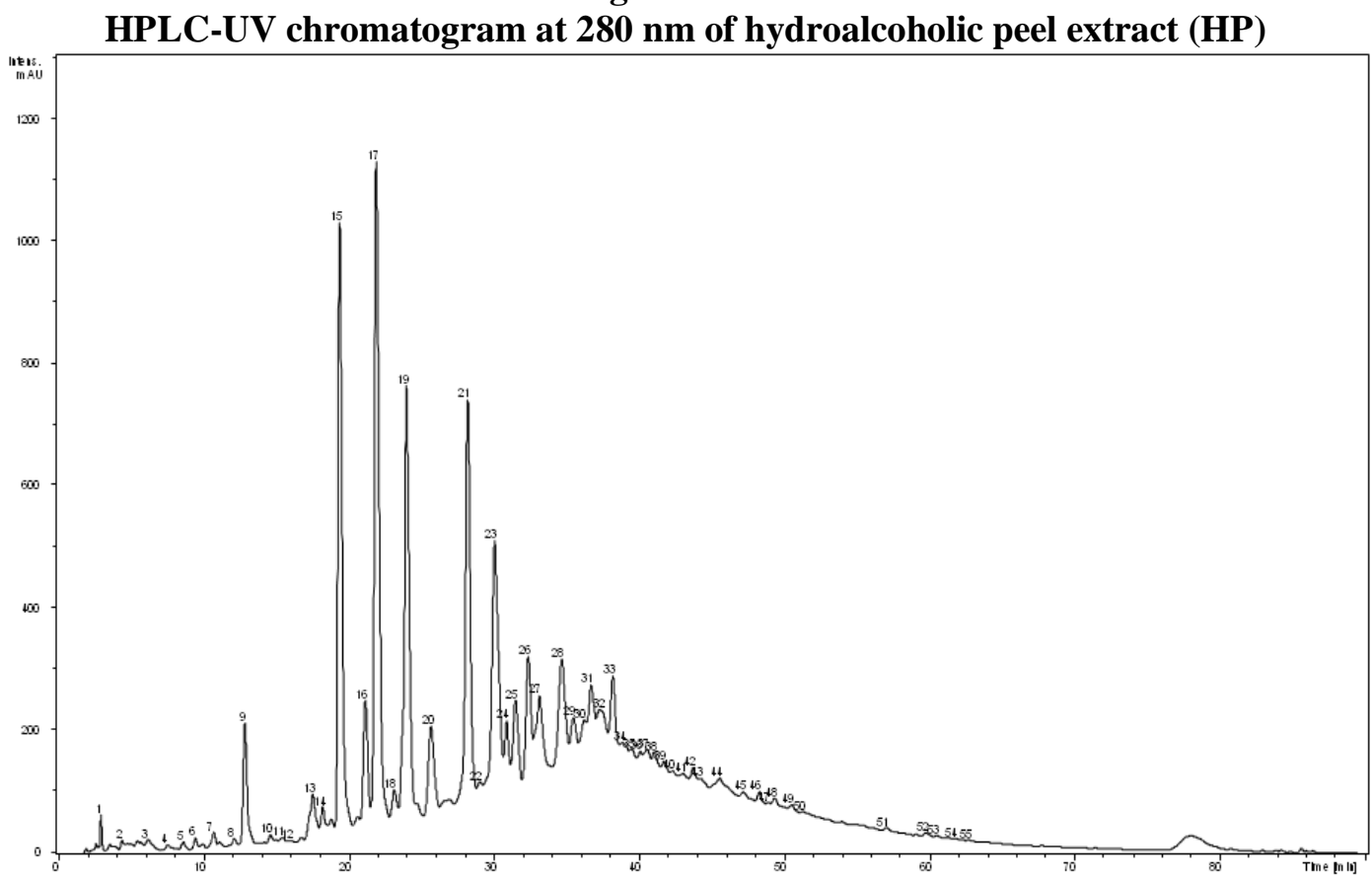

Figure No. $4 \mathrm{~S}$

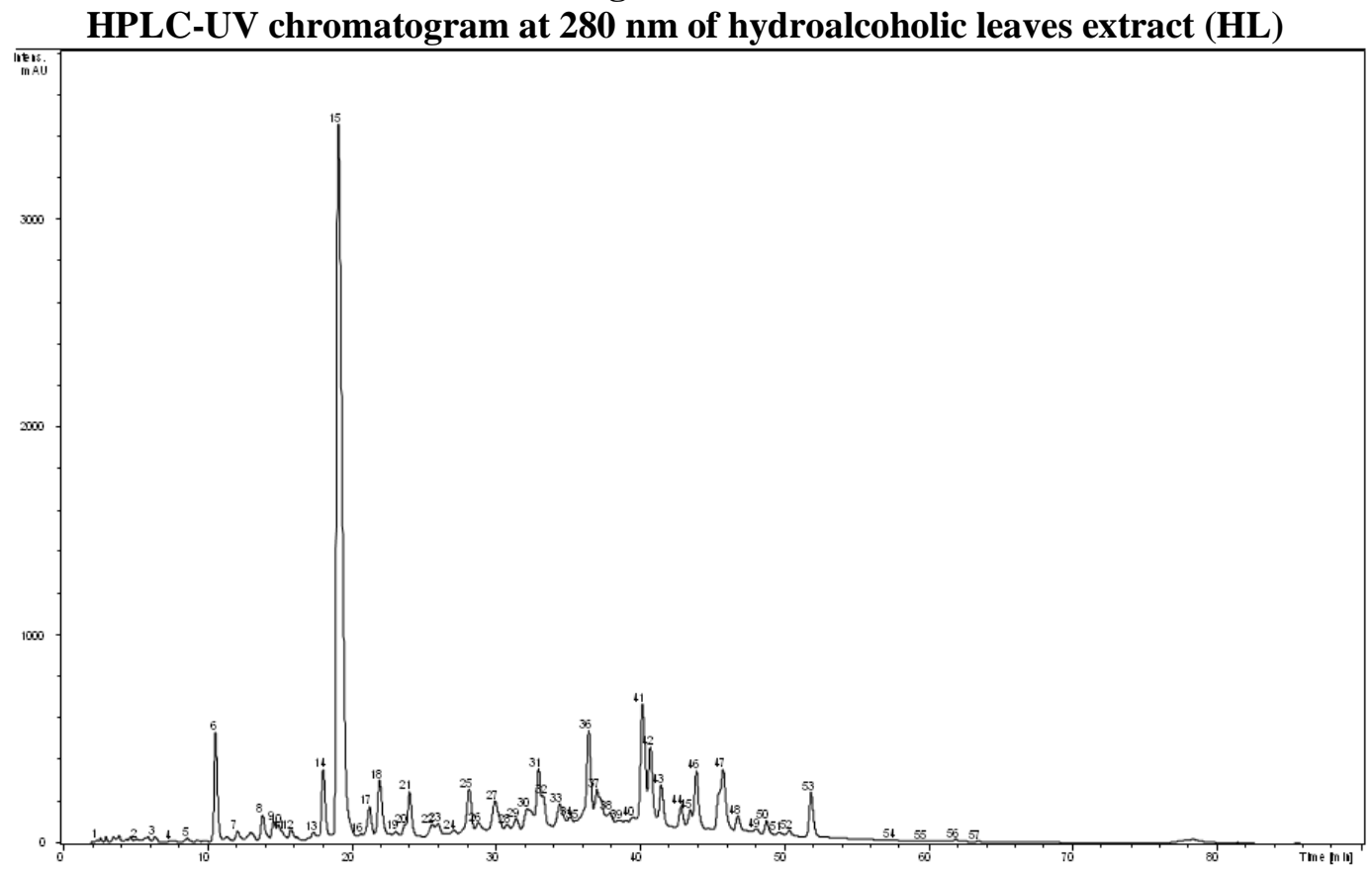

Boletín Latinoamericano y del Caribe de Plantas Medicinales y Aromáticas/407 